\title{
Enhancing Self-Esteem in Classroom Language Learning: The Potential of Implementing a Strength-Based Positive Psychology Intervention at Higher Education
}

Mehry Haddad Narafshan, Samieh Noori

Department of Foreign Languages, Kerman Branch, Islamic Azad University, Kerman, Iran.

Email: mnarafshan@yahoo.com

How to cite this paper: Haddad Narafshan, M., \& Noori, S. (2018). Enhancing SelfEsteem in Classroom Language Learning: The Potential of Implementing a StrengthBased Positive Psychology Intervention at Higher Education. International Journal of Language Teaching and Education, 2(3), 334-345.

https://doi.org/10.22437/ijolte.v2i3.5593

Accepted: October 18, 2018

Published: November 30, 2018

Copyright (c) International Journal of Language Teaching and Education.

This work is licensed under the Creative Commons Attribution International License (CC BY 4.0).

http://creativecommons.org/licenses/by/4 $.0 /$

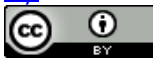

\section{Abstract}

Since positive psychology (PP) is a nascent area of research, there are very few empirical studies assessing the impact of positive psychology interventions. Accordingly, this article reports on a quantitative study concerning the use of a positive psychology intervention to develop learners' self-esteem in the context of higher education in the English as a foreign language (EFL) sector in Iran. Data was collected during the academic year 20162017 from a university in Iran using Cooper Smith $(1967,1981)$ Self Esteem Inventory Adult Form (CSEI-A) , a self-report questionnaire, as the instrument and administering it before and after a TEFL master course. Thirty six university students participated in a five-month long quasi-experimental study. The current study's primary aim was to investigate in detail the potential of PP intervention for supporting the self-esteem progress in the context in question. The study showed a statistically significant improvement in the self-esteem of the participants in the experimental group after completing the course suggesting positive paths from positive psychology to understanding the strengths and managing the weaknesses effectively. The encouraging results from this program suggest new avenues for approaching the change of self-esteem.

\section{Subject Areas}

Classroom Language Learning

\section{Keywords}

character-strength, positive psychology, self-esteem

\section{Introduction}

Positive psychology, a branch of research within the field of psychology, studies the conditions and experiences involved in human flourishing (Seligman \& Csikszentmihalyi, 2000). Despite its brief existence, since 1998, this field 
has recently gained attention and shown considerable growth in the realms of research, practice, and change. In educational settings, this popularity has generated the domain of "positive education" - a recently growing trend in educational research that aims to merge positive psychology principles with educational practices to increase learners' well-being (Seligman, Ernst, Gillham, Reivich, \& Linkins, 2009). Granted that education, especially higher education, is an influential and humanizing process by which learners' body, mind and character are strengthened, the goals of positive psychology mirror the goals of education. There is no doubt that education can be a means for expanding accumulated knowledge, values and skills to make learners capable, competent and wise in the face of the challenges of life. Higher education is an important and specialized form of human capital, which can cause public growth (Diener \& Patterson, 2011). In a word, both positive psychology and positive education seek to promote general well-being, life satisfaction and meaning across a broad spectrum from individuals to institutions' global life. The main consequence of the application of PP to education is to create a fresh learning climate in class where individual learners can use the shared information according to their own talents and views (Hayes, 2006; Hurlock, 1925; Muscott, Mann and LeBrun, 2008).; the second principle, which is at least as crucial as the first, is to promote a climate at educational settings that will foster intellectual, emotional and physical "wellbeing" in students; so as to prevent the potential academic and general problems before they occur or reoccur (Gilman, Huebner, \& Furlong, 2009; Martin, Seligman, Ernst, Gillham, Reivich \& Linkins, 2009; Murray,2003).

At present, higher education especially language learning is an anxietyprovoking experience for many students (Muchnick \& Wolfe 1982; Horwitz et al. 1986; MacIntyre \& Gardner 1991; Rubio 2004). Poor self-esteem at higher education can result in a cascade of diminishing self-appreciation and creating self-defeating attitudes, psychiatric vulnerability, and social problems. Furthermore, lack of appropriate level of self-esteem can create unpredictable problems among learners of master's degrees and may lead to present failure and future disappointment (Poorsoti \& Asadi, 2016).

In effect, to make a difference in students' academic and general life, positive psychology can be an efficient solution since it places an emphasis on learners' individual strengths and personal motivation, helping them change negative styles of thinking and increase well-being and self-esteem. According to Langley (2016), the strengths approach at the heart of positive psychology changes the focus from fixing weakness to recognizing and emphasizing what people do well and fostering their potential to develop. It assumes strengths are part of human nature; everyone has them and deserves respect for them. It also asserts we can only address our weaknesses when we make the most 
of our strengths. However, to the authors" best knowledge, no publications are available in the literature addressing the application of positive psychology, a strength-based therapy, at higher education in an EFL context. For these reasons, the present study aims to heighten students' self-esteem and develop their wellbeing in a master course of TEFL. In addition, it aimed to help learners outgrow the shell of their negative thoughts and understand their strengths. In detail it investigated the following research question: What effects can positive psychology have on EFL learners' self-esteem?.

\section{Literature Review}

Humanistic psychology developed around the middle of the twentieth century in part to highlight the fact that the previous ways of thinking in psychoanalysis and behaviorism had not been concerned with the full range of functioning. Arising from this, positive psychology is concerned with theories proposing how to make a good life. Undoubtedly, this trend in psychology is interested in the sort of learning that leads to personal growth and change and believes that the highest levels of education include personal involvement at both affective and cognitive levels.

In addition, the focus on what is good about humans and their lives has long been a matter of human research. The notion of wellbeing has been frequently used to indicate a complex concept consisting of the relative presence of positive emotions, the absence of negative emotions, and satisfaction with life (Myers \& Diener, 1995). One approach to fostering wellbeing may be to assist the development of character strengths. Character strengths are defined by Brdar and Kashdan (2010) as 'pre-existing qualities that arise naturally, feel authentic and are intrinsically motivating to use' (p. 151).On the other hand, Peterson (2006) argues that 'we should develop and use as many strengths of character as possible' (p. 157) and he also claims that educational settings are ideal settings to teach character. Character strength seeks to ensure that a student's academic abilities are developed in unison with his/her character (Berkowitz \& Bier, 2004; Lickona, 1993) which is in line with the positive education movement (Seligman, Ernst, Gillham, Reivich, \& Linkins, 2009). Benninga, Berkowitz, Kuehn, and Smith (2006) in a study to find the relationship between character education and academic achievement found that the experiences that students have in schools or universities can build their character. Character strengths can act as protective factors which help to decrease negative feelings and enable flourishing (Park \& Peterson, 2008). This includes positive introductions, where the student is asked to identify, feel gratitude for, and put strengths in action plan. 
Tudor (1996) mentions that self-concept, identity and self-esteem are among the key elements of mental health. Additionally, Porky (1970) and West, Fish, and Stevens (1980) cite a correlation between general self-esteem and academic and personal success. Thus, positive psychology calls attention to the positive feelings that a good educational climate can build. In such happy environment students obtain instructions they can process easily and retain what is learned more permanently (Cohn \& Fredrickson, 2009). In like manner, Scherer (2005) holds that positive emotions can make and guide motivational behaviours from students, enabling them to engage and solve learning tasks more effectively. As a result, good or bad emotional experiences language learners are exposed to and the sort of motivational energy they exhibit during learning activities go hand in hand (Mendez Lopez, 2011). The more language learners experience positive emotions, the more motivation they will exhibit during language learning process. Indeed, most studies show that positive emotions can stimulate learners' pleasurable engagement and involvement with their environment as well as motivate social relationships (Cacioppo, Priester, \& Berntson, 1993; Carver \& Scheier 1990; Clore 1994; Davidson 1993; Frijda 1994).

Moreover, some scholars acknowledge that foreign language learning is primarily an emotionally driven task (Maclntyre, 2002; Dörnyei, 2005; Garret \& Young, 2009; Bown \& White, 2010; Imai, 2010). MacIntyre (2002) claims that the difference between engaged and unengaged learners can be explained by the emotions they experience during the process of language learning and that these have a strong connection with their level of self-esteem. Self-esteem refers to an individual's perception of his or her own self-worth and varies between individuals (Waterman, 1992). This self-assessment is a crucial construct and is related to a variety of positive psychological outcomes, including overall psychological adjustment, positive emotion, social confidence, and life satisfaction (Diener, Emmons, Larsen, \& Griffin, 1985; Leary \& MacDonald, 2003. A review of the literature emphasises the fact that self-esteem is an important psychological factor contributing to health and quality of academic life and life in general (Evans, 1997). Recently, several studies have shown that subjective well-being significantly correlates with high self-esteem, and that self-esteem accounts for significant variance in both mental well-being and happiness (Zimmerman, 2000). Indeed, while low self-esteem leads to maladjustment, positive self-esteem, internal standards and aspirations seem to contribute actively to 'wellbeing' (Garmezy, 1984; Glick and Zigler, 1992). Also, the relationship between self-esteem and academic achievement has been well documented in the literature. A variety of studies have reached the conclusion that academic achievement and self-esteem are positively correlated (Bankston \& Zhou, 2002; Lockett \& Harrell, 
2003; Schmidt \& Padilla, 2003; Marsh and Yeung, 1997; Filozof et al., 1998; Hay et al., 1998).

To sum up, the literature review demonstrates that there is a connection between positive psychology and self-esteem. However, more empirical evidence is needed as to how positive psychology affects self-esteem. To the authors' best knowledge referring to the review of literature, there are no studies investigating positive psychology and self-esteem in an EFL context. This research is designed to address the gaps in this area. Its general aim is to provide empirical evidence on what works in a strength-based positive psychology intervention designed to develop students' self-esteem at tertiary level.

\section{Methodology}

\subsection{Participants}

This study adopted a quasi-experimental design. The participants of the study were 36 upper-intermediate MA students of TEFL between the ages of 22 and 35 enrolled in a practical teaching course in a university in Kerman, Iran. They were divided into two groups of 18 students (12 girls and 6 boys in each group). All participants had roughly the same English language learning experience with respect to the number of years they had received EFL instruction. To control for the differences attributable to nationality and first language, all participants in this study were L1 speakers of Persian from Kerman, Iran. After receiving information about the scope of the research, the data to be collected and their right to withdraw from the study at any time, all the participants confirmed their willingness to take part in the study by signing a consent form.

\subsection{Instrument}

To assess the participants' level of self-esteem, the Self Esteem Inventory Adult Form (SEI-A) developed by Cooper Smith $(1967,1981)$ was used (appendix). The twenty-five items of the questionnaire on the measure were rated on the 2-point scale of "like me" and "unlike me". The Cronbach Alpha reliability of the measure with the present sample was calculated to be 98 . Hence, the questionnaire was deemed to be a reliable instrument for eliciting the intended data

\subsection{Procedure}

In this study, the independent variable (the application of positive psychology in the classroom) is considered to have a direct effect on the dependent variable (self esteem).As the first step, the participants were assigned to two groups, a control group and an experimental group with 18 participants each, 
After The groups were provided with equal opportunities in terms of class time (an hour and a half for each session), and the number of sessions (2 sessions per week). The Self Esteem Inventory Adult Form (SEI-A) questionnaire was used to measure the primary level of the learners' self-esteem. During this period, the learners in the control group were given the same tasks as the experimental group except they were not exposed to thirty-eight SBPPC (Strength Based Positive Psychology Clips) while the participants in the experimental group engaged in a 30-mint task of SBPPC exposure which included the stages of observation and discussion.

During the observation stage, the teacher asked the learners just to watch the clips. And after watching the clips, the students started to discuss and reflect on the clips. The students discussed how the clips helped them understand to deal with negative feelings if they were experiencing distress in relations to their academic tasks for example. Bringing unhelpful thoughts such as 'I can't stand all the pressure'; 'I am not professional enough;' or 'I am going to quit.' into the student's awareness, the PP clips encouraged the student to think about a time when they completed academic tasks successfully, encouraging them to explore what they were thinking at that time and what strengths they used to help themselves.. Examples of adaptive thoughts that might surface from these positive examples include: 'This is really tough, but if I manage the time, I can cope with this task' and 'In the past I experienced the same challenges, but I did it. So, I can do my best this time, too.' In this way, the PP clips helped the students to challenge their own negative thoughts, connecting them with their own positive and adaptive thinking. Finally, after five months of SBPPC exposure, progress was evaluated by comparing the self-esteem of the control and experimental group.

\section{Findings and discussion}

As stated above, the present study was conducted with the main goal of exploring the effect of positive psychology on EFL learners' self-esteem. Consequently, a basic quantitative research design was adopted to elicit and analyse the data in the present study. To identify whether a significant change occurred in the self-esteem of each group during the study, we conducted paired samples t-test and independent t-test. The result of the paired sample t-test analysis did not show a significant difference in the mean scores for the pretest $\left(\mathrm{M}_{1}=36.61, \mathrm{SD}_{1}=3.22\right)$ and the post-test of control group $\left(\mathrm{M}_{2}=37\right.$, $\left.\mathrm{SD}_{2}=2.83\right), \mathrm{t}=0.53, \mathrm{df}=17, \mathrm{p}>0.05$. The effect size was $\mathrm{ES}=3.94$ and $\mathrm{r}=0.892$. However, the results strongly confirmed a significant difference in the mean scores for experimental group on the pre- test (M1=38.56, SD1= 2.83), and posttest $(\mathrm{M} 2=66.56, \mathrm{SD} 2=11.39), \mathrm{t}=-10.03, \mathrm{df}=17 . \mathrm{P}<0.01$, with an effect size of $E S=3.94$ and $r=0.892$, rejecting the null hypothesis and confirming 
the research hypothesis.

The result of the independent t-test analysis did not show a significant difference in the mean scores for control (M1=36.61, SD1=3.22) and experimental group on pre- test $(\mathrm{M} 2=38.56, \mathrm{SD} 2=2.83), \mathrm{t}=-1.92, \mathrm{df}=34 . \mathrm{P}<0.01$. But the results strongly confirmed a significant difference in the mean scores for control and experimental group on post- test $(M 1=37, \mathrm{SD} 1=2.83$ ), (M2=66.56, SD2=11.39), $\mathrm{t}=-10.68, \mathrm{df}=34, \mathrm{p}<0.01$, and the effect size was $\mathrm{ES}=4.16$ and $\mathrm{r}=0.901$.

Table 1. Paired T-Test of Self-esteem

\begin{tabular}{lcccccc}
\hline Time & N & Mean & $\begin{array}{c}\text { Std. } \\
\text { Deviation }\end{array}$ & $\begin{array}{c}\text { T- } \\
\text { Test }\end{array}$ & Df & $\begin{array}{c}\text { P- } \\
\text { Value }\end{array}$ \\
\hline CG & 18 & 36.61 & 3.22 & - & 17 & 0.6 \\
pre-test & & & & 0.53 & & \\
\hline post-test & 18 & 37 & 2.83 & & &
\end{tabular}

\begin{tabular}{lllllll}
\hline Time & N & Mean & $\begin{array}{l}\text { Std.De- } \\
\text { viation }\end{array}$ & T-Test & df & $\begin{array}{l}\text { P- } \\
\text { Value }\end{array}$ \\
\hline EG & 18 & 38.56 & 2.83 & -10.03 & 17 & 0.0000 \\
pre-test & & & & & & \\
\hline post-test & 18 & 66.56 & 11.39 & & & \\
\hline
\end{tabular}

Table 2. Independent T Test of Self-esteem

\begin{tabular}{lllllll}
\hline Time & $\mathbf{N}$ & Mean & $\begin{array}{l}\text { Std.De- } \\
\text { viation }\end{array}$ & T-Test & df & $\begin{array}{l}\text { P- } \\
\text { Value }\end{array}$ \\
\hline $\begin{array}{l}\text { Pre-test } \\
\text { control }\end{array}$ & 18 & 36.61 & 3.22 & -1.92 & 34 & 0.06 \\
\hline $\begin{array}{l}\text { experi- } \\
\text { mental }\end{array}$ & 18 & 38.56 & & & & \\
\hline
\end{tabular}




\begin{tabular}{lllllll}
\hline Time & N & Mean & $\begin{array}{l}\text { Std.De- } \\
\text { viation }\end{array}$ & T-Test & df & $\begin{array}{l}\text { P- } \\
\text { Value }\end{array}$ \\
\hline $\begin{array}{l}\text { Post test } \\
\text { Control }\end{array}$ & 18 & 37 & 2.83 & - & 34 & 0.000 \\
& & & & 010.68 & & \\
\hline $\begin{array}{l}\text { experi- } \\
\text { mental }\end{array}$ & 18 & 66.56 & 11.39 & & & \\
\hline
\end{tabular}

The present study investigated the effectiveness of implementing a strengthbased positive psychology intervention at higher education in EFL classes. By administering a questionnaire, quantitative data were gathered. Regarding the research question - What effects can positive psychology have on EFL learners' self-esteem - the results of this study presented in tables 1 \& 2 demonstrate that the positive psychology intervention used helped EFL learners understand and build on their strengths and manage (rather than focus on) their weaknesses in a way that increased their self-esteem. These results show that the intervention used can be recommended as a practical means to create high self-esteem classrooms for English learning.

Other studies show self-esteem is a significant construct relevant to overall psychological adjustment, positive emotions, social confidence, and life satisfaction (Diener, Emmons, Larsen, \& Griffin, 1985; Leary \& MacDonald, 2003). As mentioned earlier, positive psychology is associated with higher levels of self-esteem (Brown \& Ryan, 2003; Rasmussen \& Pidgeon, 2011; Thompson \& Waltz, 2008). Positive psychology encourages a non-judgemental, open, and receptive accessible stance to one's thoughts, emotions, and experiences (Baer et al., 2006), and this may allow individuals to be less depleted by hardship or critical, and judgmental thoughts about the self. Following Ryan, Brown, and Creswell's (2007) interesting discussion of the principles of positive psychology, the present study demonstrated that a positive psychology intervention can increase self-esteem. The PP intervention, 
working on character strength, helped the participants of the present study make positive images of themselves since PP made them able to step back from any negative thoughts arising about the self. The commonly endorsed assumption in Positive Psychology studies is that people need to feel good about themselves and try to enhance and maintain their positive self-image. It seems that the conditions boosting optimal human functioning should be emphasized at schools which in turn can help increase the learners 'self-esteem. The concept of positive psychology in education seeks not only higher academic achievement but character strengths, self-awareness and emotional control. By taking advantage of the best of Positive Psychology, strengthsbased education could positively transform of colleges and universities.

\section{Conclusions}

The current study investigated the effect of a positive psychology intervention on EFL learners' self-esteem suggesting that applying positive psychology principles can increase EFL learners' self-esteem. The findings are widely important in EFL and provide a useful intervention that educational professionals can use with students in their classrooms. The results suggest that positive psychology principles lead to significantly greater rates of improvement in EFL learners' self-esteem. Following these findings, it can be said that for inspiring and improving EFL learners' self esteem, positive psychology helps learners feel good about themselves and try to enhance and maintain their positive self-image, helping them change negative styles of thinking and increase well-being and self-esteem.

The goals of positive psychology mirror the goals of education. Most professionals enter the field of teaching to make a difference in the general and academic lives of students. What stimulates teachers to continue is the joy of seeing positive change and growth at optimal levels in students. Positive Psychology similarly promotes general well-being and life satisfaction and does so across the broad spectrum from individuals to institutions. Further, as learners work on themselves by learning the principles of this new branch of psychology they can identify and employ their real talents in learning area by eliminating mental barriers to success. This approach helps learners change negative styles of thinking and in this way change how they feel. They develop the ability to pull attention away from the chronic inner chatter of negative thoughts and redirect it to their strengths, enhancing well-being.

While this study expands upon the findings of previous self-esteem studies, it also has some limitations. In the current study, the participants were a group of university EFL learners, and so any generalization of the findings to other contexts such as private language institutes and high schools should be done with caution. The data collection was limited to a self-report questionnaire. To obtain a more precise estimate of the variables, future research should utilize qualitative methods such as interview and observation, too. It is also recommended that this study be replicated in different EFL contexts among learners with diverse cultural, educational and socioeconomic 
backgrounds. Becker and Maracek (2008) emphasized the significance of considering the individual within his/her social and cultural context and defining happiness, strengths, and virtue in whatever way is most relevant to that special context. The use of strengths models and measures must always be considered within the cultural contexts of the individuals with whom one is working. Furthermore, the study did not also include an evaluation of the program effects on the teacher who underwent positive psychology training. As the teacher was the one who shaped the emotional quality of the program content, it is possible that the teachers' emotional connection to the program content had a decisive effect that could not be reproduced by merely adhering to the guidelines with fidelity. The final limitation was the lack of time for conducting the research. Moreover, the intervention sessions were relatively lengthy, which might limit the implementation of the program due to the loss of instructional time.

\section{References}

[1] Belisle, T. A. (1997). Developing vocabulary knowledge in the immersion classroom.

[2] Baer, R.A., Smith, G.T., Hopkins, J., Krietemeyer, J., \& Toney, L. (2006).Using selfreport assessment methods to explore facets of mindfulness. Assessment, 27-45.

[3] Bankston, C. L., \& Zhou, M. (2002). Being well vs. doing well: Self-Esteem and school performance among immigrant and nonimmigrant racial and ethnic groups. International Migration Review, 36(2), 389-415.

[4] Becker, D., \& Marecek, J. (2008). Positive psychology: History in the remaking. Theory \& Psychology, 18(5), 591-604.

[5] Benninga, J. S., Berkowitz, M. W., Kuehn, P., \& Smith, K. (2006). Character and academics: What good schools do. Phi Delta Kappan, 87(6), 448-452.

[6] Berkowitz, M. W., \& Bier, M. C. (2004). based character education. The Annals of the American Academy of Political and Social Science, 591(1), 72-85

[7] Bown, J., \& White, C. J. (2010). Affect in a self-regulatory framework for language learning. System, 38(3), 432-443.

[8] Brdar, I., \& Kashdan, T. B. (2010). Character strengths and well-being in Croatia: An empirical investigation of structure and correlates. Journal of research in personality, 44(1), 151-154.

[9] Brown, K. W., \& Ryan, R. M. (2003). The benefits of being present: mindfulness and its role in psychological well-being. Journal of personality and social psychology, $84(4), 822$.

[10] Cacioppo, J. T., Priester, J. R., \& Berntson, G. G. (1993). Rudimentary determinants of attitudes: II. Arm flexion and extension have differential effects on attitudes. Journal of personality and social psychology, 65(1), 5.

[11] Carr, M., Borkowski, J.G., \& Maxwell, S. (1991). Motivational components of underachievement. Developmental Psychology, 27(1), 108-118.

[12] Carver, C. S., \& Scheier, M. F. (1990). Origins and functions of positive and negative affect: A control-process view. Psychological review, 97(1), 19.

[13] Clifton, D. O., \& Nelson, P. (1992). Soar with your strengths. New York, NY: Dell Publishing.

[14] Clore, G. L., Schwarz, N., \& Conway, M. (1994). Affective causes and consequences of social information processing. Handbook of social cognition, 1, 323-417. 
[15] Cohn, M. A., Fredrickson, B. L., Brown, S. L., Mikels, J. A., \& Conway, A. M. (2009). Happiness unpacked: positive emotions increase life satisfaction by building resilience. Emotion, 9(3), 361.

[16] Cooper smith, S. (1967). The Antecedents of Self Esteem. Freeman, San Francisco, CA

[17] Davidson R.J. (1993). The Neuropsychology of Emotion and Affective Style. In: Lewis M, Haviland JM, editors. Handbook of emotion. Guilford Press: New York. pp. 143154.

[18] Diener, E. D., Emmons, R. A., Larsen, R. J., \& Griffin, S. (1985). The satisfaction with life scale. Journal of personality assessment, 49(1), 71-75.

[19] Diener, R. B., \& Patterson, L. (2011). Positive psychology and poverty. In Positive psychology as, social change (pp. 125-140). Springer Netherlands.

[20] Dörnyei, Z. (2005). The psychology of the language learner: Individual differences in second language acquisition. London: Routledge.

[21] Evans, D. R. (1997). Health promotion, wellness programs, quality of life and the marketing of psychology. Canadian Psychology/Psychologie canadienne, 38(1), 1.

[22] Filozof, E. M., Albertin, H. K., Jones, C. R., Steme, S. S., Myers, L., \& McDermott, R. J. (1998). Relationship of Adolescent Self-Esteem to Selected Academic Variables. Journal of School Health, 68(2), 68-72.

[23] Frijda, N. H. (1994). Emotions are functional, most of the time.

[24] Garmezy, N., Masten, A. S., \& Tellegen, A. (1984). The study of stress and competence in children: A building block for developmental psychopathology. Child development, 97-111.

[25] Garret, P. \& Young, R. F. (2009). Theorizing affect in foreign language learning: an analysis of one learner's responses to a communicative Portuguese course. The Modern Language Journal, 93 (2), pp. 209-226.

[26] Glick, M. and Zigler, E. (1992). Risk and Protective Factors in the Development of Psychopathology. Cambridge University Press, Cambridge, pp. 497-513.

[27] Garmezy, N. (1992). Risk and protective factors in the development of psychopathology. Cambridge University Press.

[28] Mann, M. M., Hosman, C. M., Schaalma, H. P., \& De Vries, N. K. (2004). Self-esteem in a broad-spectrum approach for mental health promotion. Health education research, 19(4), 357-372.

[29] Hay, I., Ashman, A. F., \& Van Kraayenoord, C. E. (1998). Educational characteristics of students with high or low self-concept. Psychology in the Schools, 35(4), 391-400.

[30] Horwitz, E. K., Horwitz, M. B., \& Cope, J. (1986). Foreign language classroom anxiety. The Modern language journal, 70(2), 125-132.

[31] Imai, Y. (2010). Emotions in SLA: New insights from collaborative learning for an EFL classroom. The Modern Language Journal, 94(2), 278-292.

[32] Langley, S. (2016). Five Key Principles of Positive Psychology.http:// blog. langleygroup. com. au /five-key-principles-of-positive-psychology

[33] Leary, M. R., \& MacDonald, G. (2003). Individual differences in self-esteem: A review and theoretical integration. InM. R. Leary \& J. P. Tangney (Eds.), Handbook of self and identity (pp. 401-418). New York, NY: Guilford Press.

[34] Lockett, C. T., \& Harrell, J. P. (2003). Racial identity, self-esteem, and academic achievement: Too much interpretation, too little supporting data. Journal of Black Psychology, 29(3), 325-336.

[35] MacIntyre, P. (2002). Motivation, anxiety and emotion in second language acquisition. In P. Robinson (Ed.), Individual differences and instructed language learning (pp.45-68). Amsterdam, nl: John Benjamins Publishing

[36] MacIntyre, P. D., \& Gardner, R. C. (1991). Language anxiety: Its relationship to other anxieties and to processing in native and second languages. Language learning, 41(4), 513-534. 
[37] Marsh, H. W., \& Yeung, A. S. (1997). Academic Self-Concept and Achievement. American Educational Research Journal, 34(4), 691-720.

[38] Mendez Lopez, M. G. (2011). Emotion and language learning: An exploration of experience and motivation in a Mexican University context (Doctoral dissertation). Retrieved from etheses.nottingham.ac.uk/3175/1/555352.

[39] Muchnick, A. G., \& Wolfe, D. E. (1982). Attitudes and Motivations of American Students of Spanish. Canadian Modern Language Review, 38(2), 262-81.

[40] Poorsoti, S.\&, Asadi, N.(2016). Relationship between Iranian EFL Learner's SelfEsteem, and Grammatical Accuracy in Written Discourse. Journal of Arts \& Language Studies, 1(1),1-6.

[41] Purkey, W. W. (1970). Self concept and school achievement.

[42] Rasmussen, M. K., \& Pidgeon, A. M. (2011). The direct and indirect benefits of dispositional mindfulness on self-esteem and social anxiety. Anxiety, Stress, \& Coping, 24(2), 227-233.

[43] Rubio, F.D. (2004). La ansiedad en el aprendizaje de idiomas. Huelva: Universidad de Huelva.

[44] Rubio, F. D. (2014). Self-esteem and self-concept in foreign language learning. Multiple perspectives on the self in SLA, 4158.

[45] Ryan, R. M., Brown, K. W., \& Creswell, J. D. (2007). How integrative is attachment theory? Unpacking the meaning and significance of felt security. Psychological Inquiry, 18(3), 177-182.

[46] Scherer, K. R. (2005). Unconscious processes in emotion. Emotion and consciousness, 312-334.

[47] Schmidt, J. A., \& Padilla, B. (2003). Self-esteem and family challenge: An investigation of their effects on achievement. Journal of youth and adolescence, 32(1), 37-46.

[48] Seligman, M. E., Ernst, R. M., Gillham, J., Reivich, K., \& Linkins, M. (2009). Positive education: Positive psychology and classroom interventions. Oxford review of education, 35(3), 293-311.

[49] Thompson, B. L., \& Waltz, J. A. (2008). Mindfulness, self-esteem, and unconditional self-acceptance. Journal of Rational-Emotive \& Cognitive-Behavior Therapy, 26(2), $119-126$.

[50] Tudor, K. (1996). Mental health promotion: Paradigms and practice. London, UK: Routledge.

[51] Waterman, A. S. (1992). Identity as an Aspect of Optimal Psychological functioning.

[52] West, C. K., Fish, J. A., \& Stevens, R. J. (1980). General self-concept, self-concept of academic ability and school achievement: Implications for "causes" of self-concept. Australian Journal of Education, 24(2), 194-213.

[53] Zimmerman, S.L. (2000) Self-esteem, personal control, optimism, extraversion and the subjective well-being of Midwestern University faculty. Dissertation Abstracts International B: Sciences and Engineering, 60(7-B), 3608. 